\title{
Responsabilidade do Estado por Ato Legislativo
}

\author{
J. Cretella Júnior \\ Professor Titular de Direito Administrativo \\ da Faculdade de Direito da Universidade \\ de São Paulo
}

\begin{abstract}
SUMÁRIO: 1. Introdução - 2. Responsabilidiade como categoria juridica - 3. Evento gerador do dano - 4. Conceito de lei - 5. Lei formal danosa - 6. O Estado legislador irresponsavel - 7. Orientação francesa - 8. Lei constitucional "em tese", que causa dano - 9. Lei inconstitucional danosa - 10. Dano dia lei e indenizacão - 11. Regulamento danoso - 12. Conclusão.
\end{abstract}

\section{Introdução}

O problema, rotulado sob a denominação acima, sinônimo perfeito de outra, denominada Responsabilidade do Estado legislador, ou ainda, Responsabilidade extracontratual por ato do Estado legistador, envolve questão magna e paradoxal, qual seja a de saber se o Estado pode ser responsabilizado por prejuízos causados ao particular, em decorrência de ato legislativo.

Compreende-se que o serviço público, desempenhado por agentes do Poder Executivo e do Poder Judiciário, apresente falhas e que estas acabem causando danos ao cidadão, funcionário público ou não, empenhando a responsabilidade estatal e possibilitando ações de perdas e danos contra a pessoa jurídica pública política, responsável por prejuízos que seus agentes causem a terceiros.

Agentes públicos existem nos três Poderes. Por excelência, os agentes públicos do Poder Executivo é que causam danos ao particular, empenhando a responsabilidade da pessoa jurídica pública a que se acha vinculada a pessoa física, agindo, porém, na qualidade de funcionário do Estado. Entretanto, embora com menos freqüência, atividades dos membros do Poder Judiciário — os magistrados também podem causar dano ao cidadão. Por fim, em terceiro lugar, com incidência ainda menor, a própria lei pode ocasionar prejuízos. Nos três casos, o intermediário entre o Estado e o prejudicado é o agente público, a pessoa física que age em nome do respectivo poder a que se vincula o funcionário público stricto sensu, o juíz, o legislador. Nessas três hipóteses, lato sensu, existe o homem, a pessoa 
física que, "na qualidade de agente público", desempenha atividades danosas, desempenhando serviços públicos, julgando ou legislando.

Stricto sensu, funcionário público é o agente da Administração direta ou indireta, vinculado a Poder Executivo, mas, lato sensu, funcionário público é também o magistrado, em qualquer grau, tanto assim que, nos vários Estatutos do Funcionalismo, no Brasil, os primeiros artigos costumam fazer a ressalva de que as disposições estatutárias do diploma do funcionalismo se aplicam aos agentes dos três Poderes do Estado, bem como aos dos membros do Tribunal de Contas, exceto no que colidirem com a legislação especial. E os legisladores não representam o Estado, já que este é o somatório de todos os cidadãos?

Difícil, entretanto, é compreender que os legisladores de qualquer esfera sejam funcionários públicos ou agentes públicos, porque o regime jurídico a que se encontram submetidos de maneira alguma se identifica com o que regula o funcionalismo, em geral.

Mandatários do povo, os agentes legislativos, deputados, senadores, vereadores, são selecionados pelo voto, não estão sujeitos à hierarquia, não se submetem aos dispositivos estatutários; fazem a lei, nesta ou naquela hierarquia, dentro desta ou daquela esfera, mas fazem a lei, em conjunto, seguindo processo legislativo rígido, informado por princípios do direito constitucional. Nunca agem com culpa e muito menos, com dolo. E se, por ventura, agirem com dolo, ou com culpa, em uma de suas três modalidades, a imperícia, a imprudência, a negligência?

Por outro lado, como entender que o ato legislativo - a lei expressão incontestável da soberania nacional, possa transformar-se em fonte geradora de dano para o cidadão, empenhando, desse modo, a responsabilidade do próprio Estado, que é criador e tutor do direito?

Se a lei, ato geral e impessoal, que. se dirige à grande massa dos administrados, estabelecendo situação de igualdade para todos; se a lei, em princípio inatacável, porque expressão do anseio médio da coletividade; se a lei, produto de exigente, requintada e complexa técnica legislativa, a bem dizer se identifica com o próprio Estado, que a ela também se submete, em decorrência do princípio da legalidade ("patere legem, quam fecisti"), como pretender responsabilizar a pessoa jurídica pública política matriz por disposição legislativa que cause danos ao cidadão, pessoa política essa que também está interessada em acertar, porque abrangida pelo ato editado?

Themístocles Brandão Cavalcanti (cf. Tratado de direito administrativo, $3^{\text {a }}$ ed., 1955, vol. I, págs. 427-428), depois de assinalar que "um dos pontos mais sensíveis das doutrinas sobre a responsabilidade do Estado é aquele que se refere aos atos emanados do Poder Legislativo" (cf. Tratado, vol. I, pág. 427), indaga a seguir, com propriedade: "Se esses atos constituem a própria legalidade, a emanação da soberania nacional, através do seu órgão próprio, competente, como 
encontrar, nesses atos legais, uma fonte geradora de obrigações para o Estado?"

Citando Tirard, o mesmo autor salienta que "o ato legislativo é, por natureza, geral e impessoal" e, por isso, "não atinge particularmente situações jurídicas individuais, mas estabelece o direito em determinado país e em época dada" (cf. Tratado, vol. I, págs. 426-427).

Em sintese, a responsabilidade do Estado legislador ou a responsabilidade do Estado por ato legislativo é tema dos mais relevantes, atuais, e que tem sido levado à consideração do Poder Judiciário, mostrando-se, pois, não apenas como tema acadêmico ou teórico, mas erigindo-se em assunto de importância prática, reclamando a atenção dos especialistas.

\section{Responsabilidade como categoria jurídica}

A responsabilidade jurídica nada mais é do que a própria responsabilidade humana, in genere, transportada para o campo do direito, situação originada por ação ou omissão do agente, privado ou público, que responde com sua pessoa, bem ou cargo, em razão de ter contrariado norma respeitada pelo grupo, em que vive.

Ou o infrator responde diretamente, quando age no próprio nome, ou empenha a responsabilidade do respectivo preponente, por agir como seu preposto. Nos dois casos, a responsabilidade é, de modo genérico, a mesma.

Desdobrada em modalidades jurídicas diversas, filiadas ao protótipo comum categorial, a responsabilidade é una, típica, reunindo sempre, em essência, a entidade personativa, direta ou indireta que se projetou ou se omitiu no mundo das normas jurídicas, quebrando-as e provocando o dano, convulsão maior ou menor no sistema, desequilibrando-o, o que determina imediata recomposição do equilíbrio violado.

Como categoria jurídica, o vocábulo responsabilidade designa a "situação especial de toda pessoa, física ou jurídica, que infringe norma ou preceito de direito objetivo e que, em decorrência da infração, que gerou danos, fica sujeita a determinada sanção". O dano é causado quer diretamente, dando origem a necessária relação jurídica entre autor e vítima, quer indiretamente, por meio de interposta pessoa, gerando relação jurídica entre preponente, vinculado por ação ou omissão de seu preposto, e vítima. Bifurca-se a categoria jurídica responsabilidade em duas áreas, a do direito privado, estudada pelo direito civil, a do direito público, analisada pelo direito administrativo. Esta última é a responsabilidade pública, informada por princípios publicísticos, exorbitantes e derrogatórios do direito comum, a qual, estruturada a partir de 1873, com o caso "Blanco", acabou por ultrapassar a responsabilidade paralela do direito privado, pois coloca sempre o Estado em posição de devedor, irremediavelmente, desde que haja "dano" e "nexo causal". 


\section{Evento gerador do dano}

Regra geral, o evento ou fato gerador do dano é o homem que, por ação ou omissão, atinge a pessoa ou os bens de outro homem, responsabilizando-se ou empenhando a responsabilidade de alguém, pessoa física ou jurídica, em nome da qual desempenha atividades. A responsabilidade é, assim, direta, sem interposta pessoa, ou indireta, envolvendo preposto e preponente.

No âmbito do Poder Executivo, ou no "quantum" de Administração, que existe nos outros dois Poderes, o agente público é o causador do dano, equacionando-se, nas duas hipóteses, a responsabilidade do Estado, em decorrência do mau desempenho de serviço público, mas, no primeiro caso, temos a regra - serviços públicos normais -, no segundo caso, temos a exceção, ou seja, atividades atípicas dos outros dois Poderes.

O evento gerador do dano é, em qualquer dos casos, o homem, a pessoa física, o agente público que, na qualidade de funcionário, ocasiona o prejuízo. No fundo, mesmo quando não se descubra o agente, como no caso da falta anônima do serviço público, o homem, próxima ou remotamente, é responsável pelo dano, como no caso do dano causado "pela coisa", ou, na linguagem dos franceses, "par fait des choses"

Em decorrência das eliminações feitas, o que nos interessa, neste estudo, é a fixação do nexo causal, da relação jurídica entre a "atividade típica" de cada Poder e o dano, a saber, a conexão causal entre o serviço público jurisdicional e o prejuízo e, por fim, tema central de agora, a conexão entre o serviço público legislativo e o dano. Note-se que o ato de legislar (e não a matéria legislada) é estudada pelo direito administrativo.

Se o evento gerador do dano for o produto do processo legislativo, isto é, da lei, deverá o Estado indenizar o prejudicado?

Um dos pressupostos para o equacionamento e resolução deste problema é o do exato conceito de lei.

\section{Conceito de lei}

Lei é a declaração solene da norma jurídica feita pelo Poder competente. Regra de direito, fonte de obrigações e princípio de todo recurso, em juízo, constitui, por excelência, a fonte mais pura e profunda do direito administrativo (Manuel Colmeiro, Derecho administrativo español, $3^{\text {a }}$ ed., 1865, pág. 29).

A palavra $l e i$, na linguagem jurídica, tem duplo significado, 0 sentido formal e ou sentido material. No sentido formal, lei significa não uma parte dos direitos que compreendem o poder do Estado, mas uma forma sob a qual se manifesta a vontade do Estado, pouco importando o conteúdo dessa vontade (cf. Paul Laband, Le droit 
public de l'empire allemand, 1901, vol. II, pág. 344); no sentido material, lei quer dizer o ato jurídico que estabelece a regra de direito (cf. Paul Laband, Le droit public de l'empire allemand, 1901, vol. II, pág. 260). "Entre a lei no sentido material e a lei no sentido formal não há relação de gênero a espécie, de sentido restrito e subordinado ao sentido amplo do termo. Trata-se de dois sentidos essencialmente diversos, cada um dos quais com caráter próprio: um é o fundo, outro a forma de uma declaração de vontade. Lei pública, no sentido formal, é o ato que emana da vontade do Estado, executado e afirmado sob certa forma solene" (Paul Laband, Le droit public de l'empire allemand, 1901, vol. II, págs. 345-346) .

Em sentido formal, lei é toda disposição que emana do Poder Legislativo e que tem forma constitucional de lei (critério subjetivo), seja qual for a essência e o objeto que a identifique; no sentido material ou substancial (critério objetivo), lei é toda norma geral que o é pelo conteúdo, fundo, desde que seja editada pelo Poder Judiciário ou pelo Poder Executivo ("interna corporis"), isto é, por dois Poderes que, normalmente, não têm a função precípua de legislar.

Deixando de lado as leis materiais - "interna corporis" - que, ao que saibamos, não causaram, no direito brasileiro, até agora, nenhuma lesão sensível aos administrados a tal ponto que tenham sido objeto de exame pelo Poder Judiciário, passaremos ao exame das leis formais, incluindo, em nosso estudo, entretanto, os regulamentos, porque estes atos, sempre de índole geral, nada mais são do que regras destinadas à aplicação melhor das leis a que se acrescentam, não existindo, como em outros direitos, os "regulamentos autônomos". Além disso, em nosso direito, o próprio Poder Judiciário, solicitado a manifestar-se, já tratou regulamentos e decretos como se fossem lei, o que é inexato (cf. RDA, 8:133 e 20:42).

\section{Lei formal danosa}

As leis estão dispostas em escalonação hierárquica, a partir da Lei Maior, a Constituição, que é a lei formal, por excelência, já que de modo algum tem a participação de outros poderes. Nas Federações, temos, além da Constituição Federal, as Constituições Estaduais.

Pois bem, o problema inexiste, em relação à Constituição Federal, porque, mesmo que dispositivos constitucionais, de algum modo, pudessem ocasionar danos aos administrados, o legislador constituinte seria irresponsável, já que o texto, no todo e em suas partes, tem por base a soberania nacional e esta é incontrastável. A Constituição faz o direito originariamente, criando-o.

No entanto, o problema existe, em relação a dispositivos das Constituições Estaduais que, quando conforme à Carta Magna, não empenham a responsabilidade do Estado-membro, mas quando inconstitucionais, se causam danos, podem ser objeto de arguição de inconsti- 
tucionalidade e, portanto, de apreciação pelo Poder Judiciário sob vários aspectos.

Responsabilidade (civil ou patrimonial) do Estado, em decorrência de lei formal danosa - eis a denominação completa e precisa do tema sobre o qual estamos discorrendo. Em síntese, o Estado é responsável patrimonialmente (a) por dispositivos das Constituições Estaduais e (b) por qualquer tipo de lei ordinária, que, no todo ou em parte, causem danos a terceiros, cabendo até ação regressiva contra os legisladores que, em casos excepcionais, de dolo ou culpa, tenham contribuído para a elaboração do texto prejudicial. Havendo, por exemplo, prova de que o texto de "lei em tese", inconstitucional, foi redigido para atingir determinada porção da coletividade (ou um só membro), o prejudicado tem o direito de recorrer ao Judiciário, empregando instrumento jurídico processual adequado à espécie para responsabilizar o Estado legislador pela "pseudolei em tese" danosa.

Se da lei inconstitucional resulta dano ao particular, caberá a responsabilidade ao Estado, desde que a inconstitucionalidade tenha sido declarada pelo Poder Judiciário. Sendo a lei, em regra, comando genérico e abstrato, texto impessoal de generalidade máxima, o dano aos particulares emergirá de atos concretos praticados em decorrência da lei inconstitucional, exceto no caso raro de leis que determinem situações jurídicas individuais, que é a hipótese da "pseudolei em tese", texto que, sob a firma de regra geral e abstrata, acaba enquadrando o caso particular. Imprescindível, porém, é que se verifique o nexo causal entre a lei inconstitucional e o dano ocorrido.

Note-se que somente pelo voto da maioria dos membros do Poder Judiciário poderá ser declarada a inconstitucionalidade de lei ou ato normativo do Poder Público, cabendo depois ao Senado Federal suspender a execução, no todo ou em parte, de lei ou decreto declarados inconstitucionais por decisão definitiva do Supremo Tribunal Federal.

\section{O Estado legislador irresponsável}

"The king can do no wrong", regra que resume a posição do Estado imune a qualquer tipo de indenização, foi invocada com muito maior razão pelos adeptos da teoria da irresponsabilidade do Estado legislador, que prevaleceu durante muito tempo.

Interessante é observar-se - e isto não foi assinalado ainda pelos autores - que, no campo da responsabilidade pública, em relação aos Poderes do Estado, a evolução foi sucessiva, gradual, por períodos, tendo ocorrido, primeiro, no âmbito do Poder Executivo, a regra, depois no campo do Poder Legislativo, a exceção. Em outras palavras, o Estado foi responsabilizado, primeiro, pela atividade dos funcionários públicos, stricto sensu; em segundo lugar, pela atividade dos magistrados e, por último, pela dos legisladores. 
O caso "Blanco", de 1873, na França, que marcou nova era para o direito administrativo, referia-se tão-somente ao Poder Executivo, à responsabilidade do Estado, em decorrência de falha da máquina administrativa. A decisão anterior, de 1855, do Conselho de Estado francês, julgando o caso "Rotschild", também denominado de "O Estado devedor", responsabilizou o Poder Executivo, o que sucessivamente foi ocorrendo com as decisões "Anguet" (dano pessoal no Departamento do Correio), "Pelletier" (apreensão ilegal de edição de jornal), "Cames" (acidente em arsenal), "Lémonnier" (projétil em exercício de tiro que fere transeunte), "Mélinette" (atropelamento por veículo do serviço público), "Verbanck" (caminhão do serviço de pontes e calçadas que abalroa e mata ciclista), "Balsa de Eloka" (que soçobra e causa danos pessoais e materiais), "Feutry" (caso do demente que foge de asilo e incendeia pilhas de feno, fazendo com que o fogo atinja casa comercial vizinha). Toda a jurisprudência aqui citada é referente ao serviço público, à falha da máquina administrativa, ou, em outras palavras, ao Poder Executivo.

Mesmo o caso "Couitéas", que principiou, no Poder Judiciário, quando o proprietário, tendo tido ganho de causa, ia proceder à execução da sentença, acabou envolvendo o Poder Executivo que, aliás, por prudência, deixou de dar cumprimento ao mandado judicial, empenhando assim a responsabilidade do Estado, tendo o juiz sentenciado com base na "teoria do risco social"

No segundo momento, a responsabilidade civil do Estado refere-se ao Poder Judiciário, que Waline, com sua grande autoridade, mas sem a menor razão, neste particular, entende ser questão estranha ao direito administrativo, visto tratar-se de atividade não administrativa (cf. Droit administratif, 9a ed., 1963, pág. 909), o que, aliás, não o impediu de desenvolver a matéria, precisamente em obra concernente à nossa disciplina (cf. Waline, Droit administratif, 9a ed., 1963, pág. 909, Vedel, Droit administratif, 5a ed., 1973, pág. 421 e Rivero, Droit administratif, $9^{\text {a }}$ ed., 1980, pág. 302).

$\mathrm{Na}$ França, os exemplos, embora de certo modo raros, existem, como o famoso caso do Capitão Dreyfus e, mais recentemente, da senhora francesa acusada de colaboracionista, durante a ocupação da França pelos alemães, condenada em 1945 a trabalhos forçados perpétuos, degradação nacional, confisco de bens e, afinal, em pedido de revisão, em 1956, considerada inocente (cf. Waline, Droit administratif, 9a ed., 1963, pág. 910 e no nosso $O$ Estado e a obrigação de indenizar, 1980, pág. 153). No direito francês, além do erro judiciário, vamos encontrar ações ajuizadas contra magistrados, em virtude de dolo, concussão, morosidade nos trabalhos (Laubadère, Traité de droit administratif, $3^{\text {a }}$ ed., 1963, vol. II, págs. 631 e 650, Rivero, Droit administratif, $9^{\circ}$ ed., 1980, pág. 302, Waline, Droit administratif, $9^{a}$ ed., 1963, págs. 910-911 e Zanobini, Corso di diritto amministrativo, 6 ed., 1950, vol. I, pág. 277), configurando responsabilidade do Estado, gerada por falhas nos serviços judiciários, em decorrência de motivos 
pessoais dos juizes e agentes desse mesmo Poder. É a "prise à partie", denominação dada pelos franceses (cf. Laubadère, Traité, $3^{\text {a }}$ ed., 1963, vol. II, pág. 650 e Vedel, Droit administratif, 5 ed., 1973, pág. 423).

O terceiro momento da responsabilidade civil do Estado refere-se ao Poder Legislativo, somente levado aos tribunais franceses muito recentemente, em 1938, no caso "La Fleurette" e, em 1963, no caso "Bovero".

A doutrina, em vários países, ainda era titubeante, hesitando em tomar posição definida contra o Estado legislador responsável.

Citando as teses de doutorado de Brunet ( $L a$ responsabilité de l'État législateur, Paris, 1936) e de Kouatly ( $L a$ responsabilité de la puissance publique du fait des règlements, Paris, 1954), o professor Rivero (Droit administratif, 9a ed., 1980, § 306, págs. 300 a 302) ressalta a posição da doutrina francesa e menciona vários casos levados aos tribunais gauleses, além dos dois citados acima, a saber, em 1944, Caucheteux et Desmont e, em 1961, Lacombe. Depois das decisões dos tribunais, o artigo de Kahn (L'évolution de la jurisprudence relative à la responsabilité du fait des lois) e a tese de Morange (L'irresponsabilité de l'État législateur), ambos os trabalhos citados pelo professor Rivero, pelo menos põem em relevo a preocupação constante com o assunto.

Depois de excluir os regulamentos e frisar que o problema somente existe "no que concerne às leis formais", Rivero sustenta que o problema apenas ocorre "no silêncio da lei", porque se o texto legal excluir toda indenização pelos danos causados, ou então, como no caso das nacionalizações, fixar um "quantum" pelos prejuízos, haverá, é claro, indenização, mas "se a lei nada previu, prevalece o princípio tradicional da irresponsabilidade do Estado legisferante, facilmente se justificando o princípio: é juridicamente e politicamente impossível descobrir-se uma falha na atividade legislativa que, por definição, é soberana. Por outro lado, o juiz não pode fazer decorrer de uma lei uma responsabilidade isenta de culpa, sem endossar a vontade do legislador, isto é, substituí-lo, ficar em lugar dele" (cf. Rivero, Droit administratif, 9? ed., 1980, pág. 300, § 306).

Georges Teissier elucida que "o princípio da irresponsabilidade do Estado, em decorrência de atos do Poder Legislativo, tem sido aplicado sem contestação, mesmo nos casos em que esse Poder tenha sido exercido, na realidade, por Governo investido excepcionalmente de poderes ditatoriais" (cf. La responsabilité de la puissance publique, pág. 17).

Bielsa mostra com grande propriedade que também a aplicação da lei pode causar dano injusto, mas não ilegal, o que constituiria inadmissivel antinomia (Derecho administrativo, 5a ed., 1957, vol. V, pág. 3) .

"Sem disposição especial da lei, será absurdo jurídico pretender ter direito a ação de ressarcimento de dano patrimonial, ocasionado pela lei (cf. Fiore, Della responsabilità civile dello Stato, in Questioni 
di diritto, pág. 366, citado por Antônio Gonçalves de Oliveira, na Revista Forense, vol. 95/57).

Resta a hipótese da responsabilidade civil do Estado, nos casos em que o silêncio da lei faz supor o consentimento prévio e tácito do legislador a eventuais indenizações.

O fundamento da irresponsabilidade do Estado por ato legislativo era múltiplo, argumentando-se, em primeiro lugar, com a soberania do Parlamento e com a consideração de que a lei é a síntese da vontade geral da Nação; em segundo lugar, refletia-se, se a lei proíbe certa atividade, é porque esta é prejudicial, injusta, ou, pelo menos, em desacordo com o direito; em terceiro lugar, se o juíz atribui responsabilidade decorrente de lei, está sobrepondo-se, endossando ou substituindo-se ao legislador; em quarto lugar, o número de pessoas abrangidas pelas leis, formais ou materiais, é extenso e tão genérico, que o prejuízo se reparte por todos: é encargo ônus público geral. Se "mal de todos é mal de nenhum", o prejuízo generalizado será sofrido por toda a coletividade visada pelo texto legal; enfim, faltando o traço da individualidade, da especialidade (cf. Laubadère, Traité élémentaire de droit administratif, $3^{\text {a }}$ ed., 1963, vol. II, pág. 628), subsiste a irresponsabilidade, porque a responsabilidade exige a verificação concreta do prejuízo individual (cf. nosso $O$ Estado e a obrigação de indenizar, 1980, pág. 157).

\section{y Orientação francesa}

O Conselho de Estado Francês, em 14 de janeiro de 1938, decidiu questão da maior relevância, o "leading case" da responsabilidade do Estado por ato legislativo e, a partir desse momento, houve radical mudança de colocação, no tocante ao pagamento de indenização ao prejudicado por ato legislativo formal danoso. Foi a decisão "La Fleurette" que, em resumo, é calcada no seguinte caso concreto: "a lei, entre um conjunto de medidas destinadas a proteger a indústria produtora de leite, ameaçada de colapso total, proibiu a fabricação de produtos suscetiveis de substituírem o leite, em certas circunstâncias, o que, na realidade, incidiu sobre número reduzidíssimo de empresas e, entre elas, a Companhia La Fleurette" (cf. Rivero, Droit administratif, 9a ed., 1980, pág. 301).

A Companhia La Fleurette fabricava produtos alimentares, derivados do leite, inofensivos à saúde, mas contendo certo teor láctico, o que parecia perturbar o escoamento do produto principal, o leite. A Companhia, sentindo-se prejudicada pela lei, propôs ação contra - Estado, perante o Conselho de Estado, o qual lhe deu ganho de causa porque (a) a atividade proibida pela lei não era prejudicial, (b) o prejuízo sofrido incidia quase que totalmente sobre a empresa requerente, (c) o legislador visara a proteção de outros interesses profissionais, ou seja, os dos produtores de leite e (d) nada, nem no próprio texto da lei, nem nos projetos e trabalhos preparatórios, nem 
no conjunto das circunstâncias do caso permitiria pensar que o legislador tivesse pretendido que o interessado suportasse encargo que, normalmente, não lhe seria possivel suportar" (cf. Vedel, Droit administratif, $5^{\text {a }}$ ed., 1973, pág. 413).

Seis anos mais tarde, o Conselho de Estado também reconhecia o direito de indenização de sua empresa que estava tendo prejuízos especiais caracterizados pela proibição do emprego de glicose na fabricação de cerveja, proibição feita no interesse dos produtores de cereais (caso Caucheteux e Desmont, 21 de janeiro de 1944).

Uma terceira decisão, no caso Lacombe, em $1^{\text {\% }}$ de dezembro de 1961, mostra que o Conselho de Estado aceitou o princípio do direito à indenização pelo administrado particular, em decorrência de lei danosa.

A análise destas decisões, que aceitam, e daquelas, muito mais numerosas, que negam a responsabilidade do Estado, em matéria legislativa por motivos diversos, permite equacionar o regime da responsabilidade, admitida pelo Conselho de Estado, até a decisão Bovero, prolatada em 23 de janeiro de 1963. Tratava-se de locatário, cujo filho fora mobilizado e servira o exército francês, na Argélia, no combate aos "rebeldes", antes da Independência. O locador propõe ação de despejo, obtém ganho de causa, mas, na fase de execução, é promulgada lei que suspende os despejos contra inquilinos combatentes ou que tivessem parentes mobilizados, o que protegeu o inquilino despejado e prejudicou o proprietário que teve ganho de causa.

O proprietário recorre ao Conselho de Estado que, aceitando o princípio da igualdade de todos diante dos encargos públicos, já firmado no caso La Fleurette, responsabiliza o Estado pelo ato legislativo danoso, obrigando-o a indenizar o proprietário prejudicado (cf. Rivero, Droit administratif, 9a ed., 1980, pág. 301 e Vedel, Droit administratif, $5^{\text {a }}$ ed., 1973, pág. 415).

Vedel assinala que a unificação das teorias sobre a responsabilidade do Estado por ato legislativo está em fase de construção, podendo-se formular o princípio para o qual se orienta o direito francês, do seguinte modo: "em todas as hipóteses em que a regularidade do comportamento do poder público não pode ser contestada diante do juiz da constitucionalidade ou da legalidade stricto sensu - lei, ato de governo, decisão jurisdicional definitiva - o princípio da igualdade diante dos encargos públicos deve permitir a reparação dos prejuízos especiais que ultrapassam certo grau de gravidade, sempre que o ato prejudicial não proíbe essa reparação" (Vedel, Droit administratif, $5^{\text {a }}$ ed., 1973, pág. 416).

\section{Lei constitucional "em tese", que causa dano}

O que os autores ainda não distinguiram é a verdadeira lei "em tese", texto geral, impessoal, dirigido a todos, da pseudolei "em tese", 
texto que, na prática, enquadra pessoas certas, identificadas. Pois bem, os dois mais relevantes julgados do Conselho de Estado francês, responsabilizando o Estado pelos danos causados por leis, na realidade, são pseudoleis "em tese", já que incidiram sobre uma só pessoa ou sobre número restritíssimo e identificado de empresas. No caso La Fleurette, somente esta empresa é que propôs ação contra o Estado; no caso Bovero, um só caso foi levado perante o Conselho de Estado. Onde, nesses dois exemplos, o traço da generalidade que deve caracterizar a "lei em tese"? A rigor, temos dois atos administrativos, porque ocorreu enquadramento de situações subjetivas, individuais.

Ao tratarmos da possibilidade de impetração de mandado de segurança contra "lei em tese" (cf. nossos livros O Estado e a obrigação de indenizar, 1980, Saraiva, pág. 294; Do mandado de segurança, 2a ed., 1980, Forense, pág. 153, §93; e Comentários às leis do mandado de segurança, $2^{\text {a }}$ ed., 1980, Saraiva, pág. 157, § 45), levantamos o problema da responsabilidade civil do Estado por ato legislativo danoso, no Brasil.

Segundo pensamos a "verdadeira lei em tese", ou melhor, "lei formal, em tese", se constitucional, não empenha a responsabilidade do Estado, quando causa prejuízos, porque o dano não se concentra em um só, mas se reparte, ao ser editado o texto, por todos aqueles sobre os quais incide.

Quando o Estado causa dano ao particular, em decorrência de medidas tomadas ou de operações materiais do poder público, o princípio que informa a indenização é precisamente o da "repartição equitativa dos ônus e encargos públicos" para que um só não arque penosamente com os prejuízos.

Ora, no caso da lei constitucional danosa, lei formal "em tese", a incidência é genérica, abstrata, impessoal, de tal maneira que não se aplicam os princípios que informam o instituto da responsabilidade pública.

\section{Lei constitucional danosa}

Tanto a lei constitucional danosa como a inconstitucional danosa podem causar danos. Os danos podem atingir todos os destinários da lei ou podem incidir sobre diminuto número de cidadãos. Se a lei constitucional danosa causar danos a seus destinários, in genere, o Estado é irresponsável, porque o prejuízo se reparte por todos. Se causar danos a um só, ou a restritíssimo número, deixa a lei constitucional de ser "lei em tese" para erigir-se em ato administrativo e, nesse caso, o atingido pode recorrer aos Tribunais, mediante os adequados remédios jurídicos.

A lei inconstitucional danosa, entretanto, se causar danos possibilita, sempre, aos prejudicados, as providências jurídicas para que cessem os efeitos produzidos. Como deixar atuando dispositivos legais 
inconstitucionais? Se o ato de legislar (não a matéria legislada) é regido pelo direito administrativo, não se equipara, no caso, ao serviço público? Se este, em qualquer esfera funciona mal, não deve o Estado arcar com a responsabilidade?

"Se da lei inconstitucional resulta algum dano aos particulares, caberá a responsabilidade do Estado, desde que a inconstitucionalidade tenha sido declarada pelo Poder Judiciário. Sendo a lei, em regra, comando genérico e abstrato, o dano aos particulares emergirá de atos praticados em decorrência de lei inconstitucional, exceto no caso excepcional de leis que determinam situações jurídicas individuais, de sorte que o dano será diretamente imputável à lei inconstitucional. Isso, entretanto, não altera, em absoluto, os termos da questão. O que é imprescindível é que se verifique o nexo causal entre a lei inconstitucional e o dano ocorrido" (cf. nosso O Estado e obrigação de indenizar, 1980, ed. Saraiva, pág. 155).

Que é lei inconstitucional? Lei inconstitucional é a lei que, no todo ou em parte, ofende a Constituição (cf. Alfredo Buzaid, $D a$ ação direta de declaração de inconstitucionalidade no direito brasileiro, 1958, pág. 43). É a lei — federal, estadual, municipal — que se choca, que conflita de maneira clara com dispositivo expresso da Constituição Federal; "é a lei que contém, no todo ou em parte, prescrições incompatíveis ou inconciliáveis com a Constituição" (Lúcio Bittencourt, $O$ Controle jurisdicional da constitucionalidade das leis, $2^{\text {a }}$ ed. Forense, 1968, pág. 53). Inconstitucional é ainda a lei que, embora pelo conteúdo não conflite com nenhum dispositivo expresso da Constituição, infringiu o processo, trâmite ou iter legis, contrariando ou saltando os passos prescritos para a tramitação legislativa, na própria Constituição, desde a iniciativa até a promulgação ou sanção.

"Só excepcionalmente poderá uma lei inconstitucional atingir o particular uti singuli, causando-lhe dano injusto e irreparável. Se tal ocorrer, necessária se torna a demonstração cabal da culpa do Estado, através da atuação de seus agentes políticos, mas isto se afigura indemonstrável no regime democrático em que o próprio povo escolhe os seus representantes para o Legislativo" (cf. Lopes Meirelles, Direito administrativo brasileiro, $7^{\text {a }}$ ed., 1979, pág. 625).

A nosso ver, nas próprias palavras do autor citado, (a) se a lei inconstitucional causa dano (b) dano injusto e irreparável, (c) se houve demonstração cabal da culpa do Estado, por que motivo o Estado não responderia civilmente pelos prejuízos? Não interessa o processo de escolha democrática pelo próprio povo, porque também, mediante concurso, são escolhidos, democraticamente, objetivamente, os agentes públicos do Executivo e do Judiciário, com base no princípio da igualdade de todos perante os cargos públicos e, no entanto, cabe a responsabilização estatal. Nem por terem sido escolhidos democraticamente, os agentes políticos ou representantes do povo são perfeitos. Comemetem erros, ao legislar, causando danos e obrigando, pois, o Estado 
que representam. Não interessa a causa do erro. Interessa o dano, em primeiro lugar, depois, o nexo causal.

Elucida Guimarães Menegale que "o ato da autoridade legislativa deve confrontar-se com a Constituição e, se lhe contravier aos mandamentos, tem de ser expungido; e, se de sua promulgação ou execução proveio dano ou lesão, o Estado o reparará (Direito administrativo, $3^{a}$ ed., 1957, págs. 508-509). Em outras passagens, ressalta Guimarães Menegale: "Se o ato legislativo ofende direito individual, é lícito ao prejudicado chamar o Estado à responsabilidade pelo ato de um de seus poderes constituídos". "Se o ato legislativo, cuja aplicação, por inconstitucionalidade, se recusou, acarretou danos a alguém, caberá ao prejudicado, em seguida, propor ação por perdas e danos" (cf. Direito administrativo, $3^{\text {a }}$ ed., 1957, págs. 508-509).

O direito positivo e a jurisprudência, no tempo do Império, proclamavam a regra de direito público de que os indivíduos não podiam reclamar indenização do Estado pelos danos que as leis porventura trouxessem aos seus direitos individuais, salvo se das próprias disposições legais não resultasse o reconhecimento de um direito à reparação (cf. Amaro Cavalcanti, Responsabilidade civil do Estado, 1905, pág. 510). Tal regra de direito público, fundamentada no princípio da responsabilidade do Estado por leis prejudiciais, sofre atenuações no tempo da República: cabe agora ao Poder Judiciário julgar da validade das leis, facultando-se ao indivíduo, lesado por seus dispositivos, recorrer ao referido Poder e, assim que tiver obtido a anulaçāo da lei, poderá, conforme as circunstâncias do caso, exigir justa indenização pela lesão sofrida" (Amaro Cavalcanti, Responsabilidade civil do Estado, 1905, pág. 510).

Onde vigora o direito público federal, tal como, no Brasil, desde que as leis inconstitucionais não são aplicadas pelo Poder Judiciário e podem causar danos aos particulares, os danos causados por tais atos legislativos são ressarcíveis. A pessoa prejudicada por lei inconstitucional tem manifestamente o direito de pedir a reparação pelo dano sofrido (Pedro Lessa, Do Poder Judiciário, 1915, pág. 164).

Aguiar Dias separa a lei constitucional, válida, perfeita, da lei inconstitucional, nula, inválida.

Com apoio em Duez, sustenta Aguiar Dias que "o ato legislativo, isto é, aquele que cria uma situação jurídica geral, objetiva, impessoal, abstrata, considera-se ao abrigo da responsabilidade. Bem entendido: sempre que silencie sobre as conseqüências danosas que possa acarretar" (cf. José de Aguiar Dias, Da responsabilidade civil, $2^{a}$ ed., 1950, vol. II, pág. 238 e $6^{\text {a }}$ ed., 1979, vol. II, pág. 315). Assim, ainda seguindo Duez, afirma que "a responsabilidade extracontratual do Estado com base em ato legislativo só opera, quando o legislador expressamente a reconheça".

A seguir, tratando da responsabilidade do Estado por danos causados por lei nula, inconstitucional ou inválida, conclui Aguiar Dias, 
baseado em J. Guimarães Menegale, que tal modalidade de lei empenha a responsabilidade estatal por danos causados, porque temos um regime que nos permite impugná-la (cf. Da responsabilidade civil, $2^{\text {a }}$ ed., 1950, vol. II, pág. 241 e $6^{\text {a }}$ ed., 1979, vol. II, pág. 318).

Em síntese, grande parte da doutrina brasileira distingue entre a lei constitucional e a lei inconstitucional, concluindo que a primeira, mesmo ocasionando danos, não empenha a responsabilidade do Estado, por ser mandamento de ordem geral e impessoal, a não ser que, por exceção, passe a enquadrar situações especiais, ao passo que a segunda empenha sempre a responsabilidade do Estado, equiparando-se, de certo modo, ao serviço público que, por acidente, funciona mal.

\section{Dano da lei e indenização}

Dano é o resultado da lesão, consistindo a reparação civil na obrigação de indenizar. Verifica-se, no dano, sempre, o desequilíbrio sofrido pelo sujeito de direito, pessoa física ou jurídica, atingido no patrimônio em conseqüência da violação da norma jurídica por fato ou ato alheio. Ocorrido o dano, cabe a reparação.

No caso da responsabilidade extracontratual por ato legislativo, a reparação tem de ser considerada sob dois aspectos distintos: prejuízos causados diretamente pelo texto legislativo, ou seja, pelo próprio fato da edição da lei, ocasionando o dano e justificando a indenização e prejuízos causados em decorrência de medidas administrativas, tomadas com o objetivo de facilitar a aplicação da lei danosa (cf. Vedel, Droit administratif, 5? ed., 1973, págs. 416-417).

A primeira hipótese é a da indenização pelos prejuízos causados diretamente pelo texto legal. Promulgada a lei, uma (ou várias) de suas disposições fere direitos de certo cidadão, em especial. Dirigida, muitas vezes, ao âmbito genérico da população, impessoalmente, a lei acaba tendo campo restrito, específico, prejudicando um só - ou alguns cidadãos - jamais cogitado pelo legislador. Funcionou para uns, de longe, abstratamente, "como lei" — a generalidade —, mas para outro atuou "com endereço certo", enquadrando, assim, situações subjetivas concretas (ato administrativo), como, no exemplo citado, da decisão francesa La Fleurette, empresa atingida por texto de lei que, visando o equilíbrio geral do mercado de laticínio, acabou incidindo sobre uma só firma, em especial, prejudicando-a, ou, como no caso da decisão Caucheteux e Desmont, condenou o Estado legislador que, ao promulgar lei, aparentemente geral e impessoal, prejudicou uma só firma, fabricante de cerveja, ao proibir-lhe o emprego de certo tipo de glicose. Ou, como no caso Bovero, também citado, que incidiu somente sobre uma pessoa, que combatera na Argélia.

Para efeitos de indenização, em decorrência de danos causados por ato legislativo danoso, os requisitos exigidos assim se resumem: 1ํ) só haverá pagamento de indenização, se o próprio legislador a 
fixou ou texto legal, de modo expresso ou tácito; 2?) cabe ao juiz decidir, conforme o que a lei preceituou, caso o legislador não tenha fixado a indenização ou se tenha omitido.

Se a lei silenciou a respeito da indenização, vigoram as regras seguintes: a) não se concede indenização, se a atividade proibida era imoral, ilícita ou contrária ao interesse público; b) não se concede indenização, a não ser que o prejuízo, por sua especificidade ou gravidade, ultrapassou a média dos sacrifícios impostos pelo texto, em questão; c) não cabe indenização se o sacrifício imposto pelo legislador tem por objetivo o interesse nacional.

Cabe, entretanto, indenização, se o sacrifício imposto pela medida legislativa incide sobre interesses particulares, com a finalidade de favorecer ou proteger outros interesses privados (cf. nossa monografia Anulação do ato administrativo por "desvio de poder", 1978, pág. 208).

Quando se trata de indenização por danos causados não por dispositivos legais, em si e por si, mas por medidas administrativas destinadas à concretização da lei (regulamentos ou decretos), não se configura a hipótese da responsabilidade do Estado legislador, assunto que estamos examinando, mas de problema geral de reparação de danos, em decorrência de ilegalidades praticadas pelo Executivo, pela Administração, no exercício do poder regulamentar.

Se as medidas tomadas são legais, tudo se passa como se tais providências completassem o texto de lei. Se as medidas, embora legais, não tiverem sido determinadas pelo legislador, a Administração agiu, em virtude do poder discricionário de que dispõe, podendo, nesse caso, o prejudicado pleitear a reparação (Vedel, Droit administratif, $5^{\mathrm{a}}$ ed., 1973, págs. 416-417).

\section{Regulamento danoso}

Regulamento não é lei. É ato administrativo geral, destinado a facilitar a aplicação da lei, devendo ser "secundum legem" e, jamais, "praeter legem" ou "contra legem" Logo, forma um todo único indissociável, um conjunto, com a lei, porque no Brasil não temos regulamento autônomo, como em outros países.

Por esses motivos, a generalidade da doutrina assimila o regulamento à lei e unifica a responsabilidade legal e a responsabilidade regulamentar, tratando-as conjuntamente.

O exercício da função legislativa, entretanto, não se identifica de maneira completa com o exercício do poder regulamentar, regendo-se, em vários casos, por diferentes princípios.

"Se o regulamento ê legal", esclarece Vedel, "o problema é equacionado com fundamento no princípio da igualdade diante dos encargos públicos. Neste caso, o caráter geral e impessoal tem por efeito, na maioria das vezes, retirar dos prejuízos causados o caráter especial 
e, pois, de excluir a reparação baseada na igual repartição dos encargos públicos. Por este elemento secundário, tão-só, é que a responsabilidade ocasionada pelos regulamentos se aproxima da responsabilidade motivada pelas leis" (Vedel, Droit administratif, $5^{\text {a }}$ ed., 1973, págs. 417-418). "Se o regulamento é ilegal e causa prejuízos, o problema equaciona-se com base no elemento culpa e, alicerçado nesta, resolvido" (Vedel, Droit administratif, 5a ed., 1973, pág. 417).

Embora lei e regulamento apresentem, no Brasil, inúmeros pontos de contato (cf. a respeito nosso Tratado de direito administrativo, vol. I, pág. 298 e vol. II, pág. 129), o que é reconhecido até pela jurisprudência, tanto assim que o próprio Supremo Tribunal Federal, admitindo a responsabilidade civil da Administração por ato danoso, fundado em "decreto" estadual, depois julgado inconstitucional, decreto, aliás, com efeitos normativos (ver: STF, em RDA, 20:42), tratou o regulamento como se fosse lei, o mesmo tendo ocorrido, antes, com o antigo Tribunal de Apelação do Estado de São Paulo, como se depreende da ementa do acórdão, então prolatado (ver: TASP, em RDA, 8:133), na realidade, de maneira alguma, se confunde o desempenho da função legislativa, cujo resultado final é a lei, elaborada por todo um colegiado, com o exercício da função regulamentar, que se concretiza no decreto, editado por uma só pessoa, o Chefe do Poder Executivo. Em sentido amplíssimo, tão-só, mas sem rigor técnico, é que o termo lei abrange e absorve o regulamento, mas este é apenas auxiliar das leis, procurando explicitar-lhes o sentido, jamais podendo tomar-lhes o lugar.

Havendo, no regulamento, alteração ou extinção de direitos, não há regulamento, mas abuso do poder regulamentar, invasão na competência do Poder Legislativo, porque o regulamento exorbitou, ultrapassando o terreno em que deveria movimentar-se. Se o regulamento é ilegal ou inconstitucional, se o processo de edição do regulamento se desvia ("ultra", "praeter" ou "contra" legem) das normas traçadas para seu nascimento válido, ou se contém disposições conflitantes com o texto legal matriz, o regulamento é passível de revisão judicial para que seus efeitos danosos não afetem o patrimônio dos administrados.

Se o regulamento defeituoso, na forma ou no conteúdo, pode causar danos, o Estado responde pelos prejuízos advindos. No entanto, mesmo o regulamento imune de vícios, mas despido do caráter de generalidade, acaba eventualmente por atingir uma só pessoa, física ou jurídica, o que também possibilita a responsabilidade da Administração, obrigada a ressarcir os danos ocasionados.

\section{Conclusão}

Estamos sustentando, neste trabalho, que o Estado é responsável pelos danos resultantes das atividades ocorridas no âmbito dos três Poderes, inclusive na esfera do Legislativo. Se o Legislativo, portanto, promulgar lei danosa, o Estado é civilmente responsável pelos 
danos causados a um ou a número certo e identificado de administrados, o que, de maneira alguma, configura "antinomia inadmissivel", porque "dano injusto" não é "dano ilegal", conforme acentua Bielsa (cf. Derecho administrativo, $5^{\text {a }}$ ed., 1957, vol. V, pág. 3). Nem tal colocação conflita com a noção de soberania, estranha ao caso, porque responsável não é o Estado, entendido como "síntese dos poderes soberanos", mas o Estado definido como "pessoa jurídica pública, sujeito de direito", no Brasil, a União, os Estados-membros, os Municípios.

Precisamente pela importância de que se reveste, o ato legislativo deve ser elaborado com toda a atenção exigida pela técnica de legislar, cabendo ao legislador o exame global do alcance da norma editada, inserindo-se no texto normas termostáticas de equilibrio sócio-econômico, que restabeleçam, no caso de dano específico a um só, a justa distribuição dos encargos a todos os membros da coletividade, pelo pagamento da indenização.

Se apesar de todo o cuidado, o ato legislativo, mesmo perfeito, ocasiona lesão ao particular, o dano ocasionado empenhará a responsabilidade civil do Estado, já que o legislador claudicou em sua missão legislativa.

Extinção de empresa pública, quer a que preste serviço público, propriamente dito, quer a que desempenhe atividade econômica, industrial ou comercial, empenhará sem dúvida a responsabilidade patrimonial do Estado, se a iniciativa, lei, ou ato administrativo (art. 178 do Decreto-lei $\mathrm{n}^{\circ}$ 200) causar danos a terceiros.

Famoso, no Brasil, o caso da Empresa Revista do Supremo Tribunal Federal, cujo contrato para a publicação de julgados de nossa Corte Máxima foi anulado pelo Poder Legislativo, em razão do que se apurou no inquérito que a Câmara dos Deputados mandara abrir. Absorvendo os haveres daquela Sociedade, a Câmara reconheceu a obrigação de indenizar os credores, de acordo com o exame dos livros da empresa, que deveriam revelar quais os créditos atingidos pelo benefício da lei (cf. Lei $\mathrm{n}^{\circ}$ 2.981, de 18 de dezembro de 1925). Em decisão posterior, o Supremo Tribunal Federal reconheceu o direito à indenização pelo material apreendido pela União e destinado aos fins da mencionada Revista, isto é, à execução do contrato (cf. Diário da Justiça de 10 de outubro de 1943).

Apesar de tudo, porém, não se admitiu a indenização pelas perdas e danos conseqüentes à anulação do contrato pelo Poder Legislativo. Não mereceu, no caso, acolhida, a tese da responsabilidade do Estado por ato legislativo, embora este houvesse anulado contrato em plena vigência e para cuja conclusão havia participado com a votação dos créditos necessários, mas cuja imoralidade foi apurada em inquérito instaurado (cf. Brandão Cavalcanti, Tratado de direito administrativo, 3. ed., 1955, vol. I, pág. 432).

Em 25 de novembro de 1957, a Sexta Câmara Civil do Tribunal de Justiça de São Paulo teve ocasião de examinar texto de lei expro- 
priatória municipal, reconhecendo-lhe a inconstitucionalidade, determinando, depois, a remessa dos autos ao Tribunal Pleno, conforme a Constituição. Como da demanda resultassem despesas de vulto, tais despesas foram debitadas ao Município, "primeiro, por sua ação, promulgando-a, depois, por sua omissão ou inércia, deixando que se aniquilasse pelo decurso do tempo" (cf. TJSP, em RDA, 56:243).

Mais recentemente, a Terceira Turma do Tribunal Federal de Recursos decidiu que "embora a doutrina brasileira tenha como insustentável a responsabilidade civil do Estado por ato legislativo, admite-se a responsabilidade por ato regulamentar" (TFR, em RDA, 144: 162).

$\mathrm{Na}$ realidade, é inexata a afirmação, no tocante à posição da doutrina pátria, já que em todo o corpo do acórdão apenas dois autores são citados. Um deles, Brandão Cavalcanti, na verdade, é pela tese da irresponsabilidade do Estado apenas quando se trata de lei constitucional, mas, quando se trata de lei inválida ou inconstitucional, o mesmo autor se inclina pela tese da responsabilidade do Estado. Assim: "A nulidade da lei ou de apenas alguns de seus dispositivos, por violar garantias constitucionais, justifica a responsabilidade, quando, de sua aplicação, resultar prejuízo patrimonial. É a conseqüência lógica da aplicação de uma lei que, em todo, ou em parte, é inexistente porque fere de frente a norma constitucional" (cf. Tratado de direito administrativo, $3^{\text {a }}$ ed., 1955, vol. I, pág. 437).

Amaro Cavalcanti também se filia à mesma colocação, escrevendo: "Decerto, declarada uma lei inválida ou inconstitucional por decisão judiciária, um dos efeitos da decisão deve ser logicamente o de obrigar à União, Estado ou Município, a reparar o dano causado ao indivíduo, cujo direito fora lesado, quer restituindo-se-lhe aquilo que indevidamente foi exigido do mesmo, como sucede nos casos de impostos, taxas ou multas inconstitucionais, quer satisfazendo-se os prejuízos, provadamente sofridos pelo indivíduo com a execução da lei suposta" (cf. Responsabilidade civil do Estado, pág. 511).

No mesmo sentido, Pedro Lessa (Do Poder Judiciário, 1915, pág. 164) Aguiar Dias (Da responsabilidade civil, 6a ed., 1979, vol. II, pág. 138), Guimarães Menegale (Direito administrativo, 3a ed., 1957, págs. 508-509) sustentam a tese da responsabilidade civil do Estado, em decorrência de ato legislativo ilegal ou inconstitucional.

O Supremo Tribunal Federal a todo momento tem sido solicitado a manifestar-se a respeito de matéria concernente "ao mandado de segurança contra lei em tese", que a Súmula 266 não admite, bem como sobre o tema, petrificado na Súmula 510 ("Praticado o ato por autoridade, no exercício de competência delegada, contra ela cabe o mandado de segurança ou a medida judicial").

A evolução do trabalho pretoriano da Corte Suprema suscitou prolongados debates, a partir de 1962, quando o então Ministro Antônio Gonçalves de Oliveira teve de julgar questão referente a outorga espe- 
cial de trigo mediante Decreto, depois revogado, caso que envolvia problema do âmbito do poder regulamentar e possível direito adquirido, passando-se, depois, ao bem fundamentado voto vencido do Ministro Décio Miranda, em que, mediante interposição do recurso extraordinário, candidata a concurso público defendia o direito de inscrever-se, chegando-se, por fim, à orientação do Plenário, no julgamento de mandado de segurança que investia contra Decreto do Presidente da República, fixando níveis de salário mínimo.

O Ministro Rafael Mayer, analisando a Súmula 266, repeliu a invocada preliminar de descabimento do "writ", salientando, em seu magnífico voto: "Também cabe desacolher o argumento relativo ao não cabimento do mandado, sob o color de que ele se propõe contra lei de tese, ou seja, de igual, o decreto ou ato normativo de caráter geral, emanado do Poder Executivo, que seria, ainda assim, lei no sentido material. A proposição é de ser admitida, em princípio; mas inaplicável à hipótese. Mesmo que o Decreto tenha por missão editar normas gerais, ele pode ser dotado de caráter próprio de execução, e concretude, capaz de, nessa formulação, afetar direitos. O Decreto sobre salário mínimo tem por objeto principal a instituição de escalas tarifárias, que são de aplicação imediata, alcançando, per se, a órbita dos interesses pessoais representados no direito ao salário mínimo, garantido pela Constituição e pela Lei. A simples edição do salário mínimo repercute no patrimônio dos assalariados. Portanto, é uma vantagem que lhes é conferida e, desde logo, assegurada, não se podendo, pois, assimilar a situação à de uma lei em tese, abstrata e geral, onde ainda não há efetiva constrição do direito como naquela outra. Cuido, assim, que o mandado de segurança não é inadequado para proteger contra o que é desenhado como danoso, de modo atual, ao direito do indivíduo. Não é, pois, de rejeitá-lo liminarmente". Seus pares, os ilustres Ministros, Cunha Peixoto, Décio Miranda e Soares Muñoz, o acompanharam, salientando este último, em voto lapidar: "O Decreto, atacado no mandado de segurança, é ato executório, pois fixou o salário mínimo para as diversas regiões do país e, contra os atos executórios, cabe mandado de segurança. Até contra lei auto-aplicável cabe mandado de segurança". Meu eminente e culto colega de Congregação na Faculdade de Direito de S. Paulo, o erudito Ministro Moreira Alves, votou, porém, em sentido contrário, por entender que "decreto que estabelece salário mínimo não é ato administrativo, no sentido de atribuir a determinadas pessoas um direito".

Por fim, o plenário do Supremo Tribunal Federal, ao julgar outro mandado de segurança, reconheceu a possibilidade de impetração daquele remédio heróico contra ato normativo que produz efeitos concretos, só não tendo sido reconhecido o "writ" por mero lapso do impetrante, consistente em defeito de técnica processual, não pela matéria suscitada.

No entanto, a colocação dos Ministros Cunha Peixoto, Décio Miranda, Soares Muños e Rafael Mayer, na vanguarda do controle juris- 
dicional de qualquer ato do poder público que lese direito líquido e certo do administrado, mostra a relevância da progressiva construção pretoriana da Corte Suprema da Nação, constituída não só por professores de direito, como Alfredo Buzaid, Moreira Alves e Oscar Dias Correia, como de antigos integrantes do Tribunal Federal de Recursos, Décio Miranda, Neri da Silveira, Aldir Passarinho, especializados no julgamento de matéria administrativa, na Corte de que provieram, que é como um verdadeiro Tribunal Administrativo, como ainda por nomes que integraram os mais altos postos na Administração Direta Federal, Francisco Rezek e Rafael Mayer e, finalmente, pelos julgadores Djaci Falcão e Soares Muñoz.

Em sintese, com apoio em excelentes doutrinadores, sustentamos a responsabilidade civil do Estado em decorrência (a) de ato legislativo danoso, embora perfeito e constitucional desde que, configurando-se como medida geral e impessoal, na aparência, na verdade se apresente como pseudolei em tese; (b) de ato legislativo danoso imperfeito, ilegal ou inconstitucional; (c) de ato regulamentar ou decreto que exorbite da lei, em que se apóia, hipóteses esta que o Poder Judiciário tem examinado, inexplicavelmente, como "ato legislativo" e não como "ato administrativo" 